\title{
Corrigendum to "Numerical Simulation of Copper Indium Gallium Diselenide Solar Cells Using One Dimensional SCAPS Software [J. Nig. Soc. Phys. Sci. 3 (2021) 48-58, https://doi.org/10.46481/jnsps.2021.133]"
}

C. O. Lawani ${ }^{\mathrm{a}}$, G. J. Ibeh ${ }^{\mathrm{a}}$, O. O. Ige ${ }^{\mathrm{a}}$, Eli Danladi ${ }^{\mathrm{a}, \mathrm{b}, *}$, J. O. Emmanuel ${ }^{\mathrm{a}, \mathrm{c}}$, A. J. Ukwenya ${ }^{\mathrm{a}, 1}$, P. O. Oyedare $^{\mathrm{d}}$

The original content of this published Article has an error in the name of one of the co-authors Eli Danladi which was written incorrectly as D. Eli. We highly regret this.

\footnotetext{
${ }^{*}$ Corresponding author tel. no: +2348063307256

Email address: danladielibako@gmail.com (Eli Danladi)
} 